\title{
Medical Students' Curiosity, Exploration and Engagement Levels in Online Learning Environments during COVID-19
}

\section{Çetin Toraman}

A̧sst. Prof., Çanakkale Onsekiz Mart University, Turkey, toramanacademic@gmail.com

Covid-19 pandemic has had a great impact on the educational practices throughout the world and tremendously effected the way we teach and learn. This study aims to examine the levels of medical students' curiosity and exploration, classroom engagement and commitment to online learning environment during the COVID-19 pandemic as well as to analyze the relationship between these variables. This study employs a correlational research approach method. Data were collected online from 618 students who study at the faculty of medicine using "Trait Curiosity and Exploration Inventory", "Student Engagement Scale in Distance Education" and "Classroom Engagement for University Students" and analyzed through descriptive statistics. The results revealed that the curiosity and exploration levels of the students are higher than their perception of engagement in the face-to-face classes whereas it is lower in student engagement in online learning environment. Perception level of curiosity and exploration estimates cognitive level activities more than behavioral and affective level activities.

Keywords: covid-19, distance education, classroom engagement, curiosity, online learning environment

\section{INTRODUCTION}

The term "distance education" is used as a form of education in which educators, learners and sources do not coexist, and do not share the same physical learning environment. Distance education, which started with the use of letters and continued with the use of internet, has developed into a new era during the Covid-19 pandemic due to the closure of the schools and universities. However, we have to be careful about using the term "distance education" owing to the fact that it refers to a process which requires a careful planning, design and development of certain objectives to create an effective learning ecology (Bozkurt \& Sharma, 2020). Therefore, this process during the Covid-19 pandemic have been expressed using different terms in different countries (e.g., distance education, e-learning, online education, homeschooling, etc.). Researchers conducting studies in the fields of distance education and instructional technology suggest it is better to use the term "emergency remote teaching $(E R T)$ " rather than "distance education" as this educational process is carried out under extraordinary conditions.

The term "distance education" does not fully cover those applied when education is interrupted due to the conditions similar to pandemic. Instead, it could be more convenient to use the term "emergency". In addition, the focus on the concept of "teaching" instead of "education" stems from the fact that this process is carried out under the responsibility of the educators. Another difference between "emergency remote teaching" and "distance education" is that ERT is a need or necessity due to crisis circumstances while distance Education refers to an alternative or option. It is very important to approach these terms within this context as using inappropriate terms or definitions may result in wrong practices. Furthermore, distance education is a carefully planned process, and it is based on theoretical and practical knowledge specific to the field it is applied. Emergency remote teaching is about keeping education alive with all available resources (offline and online) in crisis circumstances.

Citation: Toraman, Ç. (2021). Medical students' curiosity, exploration and engagement levels in online learning environments during covid-19. Anatolian Journal of Education, 6(2), 27-36. https://doi.org/10.29333/aje.2021.623a 
In this context, it is very important to create a learning environment that supports different types of interaction in order to ensure both cognitive and social engagement of learners living in different places (Bozkurt et al., 2020; Hediansah, \& Surjono, 2019; Hodges et al., 2020; Polat, 2020). As a result, regardless of what terms are used, this process is an exceptional period in the history of education, especially in the field of instructional technology and distance education (Yildırım, 2020).

Although distance education is appropriate in a wide variety of contexts due to its flexibility and can potentially employ rich multimedia materials, there are some problems related to students' engagement in the learning process (Sun \& Rueda, 2012). Since instructors and peers are not physically present in the same place, they may have difficulty in communication, collaboration, collective reflectivity, getting feedback and many other issues (Dumford \& Miller, 2018; Kahn, Everington, Kelm, Reid \& Watkins, 2017). In addition, due to the lack of engagement in online settings, students may feel more isolation from the educators and their peers (Farrell \& Brunton, 2020; Roddy et al., 2017), and they may lose their curiosity, interest and concentration easily (Aguilera-Hermida, 2020; Alabbasi, 2017; Kim et al., 2017). Therefore, online learning environments should be designed considering the learner needs (Brouns et al., 2017; Ferreira, MacLean \& Center, 2018). This study aims to examine the levels of medical students' curiosity and exploration, classroom engagement and commitment to online learning environment during the COVID-19 pandemic as well as to analyze the relationship between these variables. This research is unique in that the participants are selected from the medical faculty only. Considering the sample size and the type of participants, I believe this study will shed light on the difficulties that medical students have had during the COVID-19 pandemic and also reveal important findings about the design of learning environment regarding students' reflections about curiosity, exploration, classroom engagement and commitment to online learning.

\section{METHOD}

\section{Research Design}

This study has been designed according to the type of correlational research in which the researcher measures two variables and assesses the statistical relationship between those variables (Fraenkel, Wallen, \& Hyun, 2012). The study focuses on the examination of the levels of medical students' curiosity and exploration, classroom engagement and commitment to online learning environment during the COVID-19 pandemic as well as to analyze the relationship between these variables.

\section{Participants}

The research was conducted at Çanakkale Onsekiz Mart University, Faculty of Medicine with the approval of the Scientific Research Ethics Committee of Çanakkale Onsekiz Mart University. The data were collected during the COVID-19 pandemic. In this period, medical students (year 1-3) conducted their studies online, 4th and 5th year students through hybrid combination of online and face-to-face) learning, and 6th year students through face-to-face learning environment. Therefore, the Ethics Committee suggested that the data should be collected online, and the data collection form was uploaded to university online platform. In this platform, the students were asked to read the related information about the research and give their consent if they would like to participate in the study. The students who did not accept to participate did not see the scale items related to the study. In this way, data were obtained from 618 students in total out of 994 students (according to 2020-2021 Academic Year) who study at the Faculty of Medicine, Çanakkale Onsekiz Mart University. The participation rate is $62 \%$, which indicates that the data could not be obtained from the entire population. Therefore, purposive sampling method was adopted. The researcher, while using purposive sampling, determines the characteristics of the people who will form the research population and aims to reach the people who have certain characteristics (gender, years of study, be as a medical student, etc.) determined previously. Based on the information about the population, the participants who can provide the best information for the purpose of the research are selected (Christensen, Johnson, \& Turner, 2014; 
McMillan \& Schumacher, 2014). Table 1 indicates the distribution of students in the study group in terms of gender and classes.

Table 1

The distribution of participants by gender and classes

\begin{tabular}{llll}
\hline Variables & & f & $\%$ \\
\hline \multirow{2}{*}{ Gender } & Female & 326 & 52.8 \\
\cline { 2 - 4 } & Male & 292 & 47.2 \\
\hline \multirow{5}{*}{ Years } & Year 1 & 152 & 24.6 \\
\cline { 2 - 4 } & Year 2 & 173 & 28 \\
\cline { 2 - 4 } & Year 3 & 183 & 29.6 \\
\cline { 2 - 4 } & Year 4 & 14 & 2.3 \\
\cline { 2 - 4 } & Year 5 & 88 & 14.2 \\
\hline & Year 6 & 8 & 100 \\
\hline Total & & 618 & 1.3 \\
\hline
\end{tabular}

\section{Data Collection Tools}

In this study, the data were collected through three different tools described in the following:

Trait Curiosity and Exploration Inventory: The scale developed by Kashdan et al. (2009) was adapted to Turkish by Acun, Kapıkıran and Kabasakal (2013). The scale aims to examine how individuals perceive themselves in terms of their curiosity and exploration traits. The adaptation study was carried out with the data collected from university students. The scale consists of two subscales: flexibility (Item 1, 3, 4, 5, 7 and 9) and accepting uncertainty (Item 2, 6, 8 and 10), and it was designed using 5point Likert structure. There are no reverse scored items in the scale. In the adaptation of the scale into Turkish culture, the confirmatory factor analysis fit-indexes were determined as $\mathrm{X} 2 / \mathrm{df}=2.04$, $\mathrm{RMSEA}=.05, \mathrm{SRMR}=.04, \mathrm{CFI}=.98$, and NNFI=.97. The Cronbach Alpha reliability co-efficient of the scale was determined as .81 .

Student Engagement Scale in Online Learning Environment: The scale developed by Sun and Rueda (2012) was adapted to Turkish by Ergün and Koçak Usluel (2015). The purpose of the scale is to reveal how individuals perceive themselves about their commitment to online learning environment in distance education and their general level of engagement in this environment. The adaptation study was carried out with the data collected from university students. The scale consists of three subscales: behavioral engagement (Item 1-5), emotional engagement (Item 6-11), and cognitive engagement (Item 12-19), and it was designed using 5-point Likert structure. Items 2, 3 and 11 are scored in reverse in the scale. In the adaptation of the scale to Turkish Culture, the confirmatory factor analysis fit-indexes were determined as RMSEA=.07, $\mathrm{SRMR}=.05, \mathrm{GFI}=.89, \mathrm{AGFI}=.86, \mathrm{CFI}=.96$, NNFI=.96, and IFI=.96. The Cronbach Alpha reliability co-efficient of the scale was determined as .90.

Classroom Engagement for University Students: The scale was developed by Eryllmaz (2014) to determine the classroom engagement levels of university students. However, the scale was designed to reveal how students perceive themselves at the level of engagement in the physical learning environment rather than online. The scale development study was carried out with the data collected from university students. The scale consists of three subscales: emotional engagement (Item 1-5), behavioral engagement (Item 6-10), and cognitive engagement (Item 11-15). The scale has a 5-point Likert structure. There are no reverse scored items in the scale. The Cronbach Alpha reliability value of the scale was determined as .92.

\section{Data Analysis}

The data were transferred to the $\mathrm{R}$ which is a free statistical software. Students' curiosity and exploration, class engagement, and online learning environment engagement levels were analyzed 
using descriptive statistics (mean, standard deviation, median, minimum and maximum points). The relationship between the variables is modeled with multivariate regression equation.

The multivariate linear regression model has the form.

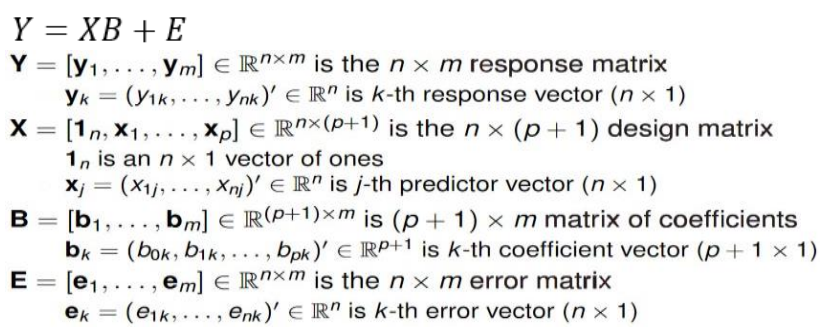

For multivariate regression modeling, the prerequisite for the data to have a normal distribution was ignored. Tests which focus on normality are hypersensitive tests (Tabachnick \& Fidell, 2013). In addition, in many studies, especially in social sciences, the measurements of dependent variables do not correspond to normal distribution (Pallant, 2016). The Central Limit Theorem suggests that if the sample is large enough $(n=30+)$, the sampling distribution of the means will be normally distributed regardless of the distribution of the variables, and the normal distribution violation will not cause a major problem (Everitt \& Howell, 2005; Field, 2018; Pallant, 2016; Tabachnick \& Fidell, 2013). In large samples, skewness does not deviate from normal distribution significantly. Positive kurtosis in a sample size of more than 100, and negative kurtosis in a sample larger than 200 begin to disappear (Tabachnick \& Fidell, 2013). Within this context, multivariate regression analysis was used in the analysis.

\section{FINDINGS}

"Student Engagement Scale in Online Learning Environment (SESOLE)" was applied to the participants. The descriptive statistics of the responses given by 618 students from the year 1-6 are shown in Table 2.

Table 2

Medical students' engagement to online learning environments

\begin{tabular}{lll}
\hline Items of Student Engagement Scale in Online Learning Environment & $\begin{array}{l}\text { Mean (Std. } \\
\text { Deviation) }\end{array}$ & $\begin{array}{l}\text { Median (Min- } \\
\text { Max) }\end{array}$ \\
\hline I follow the rules of the online class. & $3.88(0.99)$ & $4(1-5)$ \\
\hline I have trouble using the online class. & $3.35(1.01)$ & $3(1-5)$ \\
\hline I act as if I am learning in the online class. & $3.17(1.00)$ & $3(1-5)$ \\
\hline I can consistently concentrate when I am taking the online Class. & $2.61(1.07)$ & $3(1-5)$ \\
\hline I complete my homework on time. & $3.84(1.04)$ & $4(1-5)$ \\
\hline I like taking online classes. & $2.91(1.11)$ & $3(1-5)$ \\
\hline I feel excited by my work at the online class. & $2.76(1.04)$ & $3(1-5)$ \\
\hline Online classroom is a fun place to be. & $2.46(1.09)$ & $3(1-5)$ \\
\hline I am interested in the work at the online class. & $2.85(1.04)$ & $3(1-5)$ \\
\hline I feel happy when taking online class. & $2.71(1.08)$ & $3(1-5)$ \\
\hline I feel bored in online classes. & $2.63(1.01)$ & $3(1-5)$ \\
\hline I check my schoolwork for mistakes. & $3.75(0.97)$ & $4(1-5)$ \\
\hline I study at home even when I do not have a test. & $3.33(0.99)$ & $3(1-5)$ \\
\hline $\begin{array}{l}\text { I try to look for some course-related information on other resources such as TV, journal papers, } \\
\text { magazines, etc. }\end{array}$ & $3.41(0.97)$ & $3(1-5)$ \\
\hline When I read the course materials, I ask myself questions to make sure I understand what it is about. & $3.41(0.94)$ & $3(1-5)$ \\
\hline I read extra materials to learn more about the things we do in the online classes. & $3.38(0.96)$ & $3(1-5)$ \\
\hline $\begin{array}{l}\text { If I do not know about a concept when I am learning in the online class, I do something to figure it } \\
\text { out. }\end{array}$ & $3.67(0.92)$ & $4(1-5)$ \\
\hline If I do not understand what I learn online, I go back to watch the recorded sessions and learn it. & $3.78(1.03)$ & $4(1-5)$ \\
\hline I talk with the people outside of school about what I am learning in online classes. & $3.32(1.01)$ & $3(1-5)$ \\
\hline N=6l8 & \\
\hline
\end{tabular}


SESOLE, according to the items with high mean score about online learning environments, revealed that students follow the rules, complete their homework on time, check whether they made any mistakes in the homework, they do something to figure it out when they do not understand while learning online, and when they could not learn a subject online, they watch the recorded sessions again and learn it. According to these findings, it can be stated that medical students often try to adapt to the online classes and want to benefit from this environment. These findings correlate with several studies in the literature (Rajab, Gazal \& Alkattan, 2020; Zheng \& Zhang, 2020). However, when the items with low mean were examined, it was also determined that the students had problems with concentration in the online environment, they do not feel excited about online classes and do not consider learning online as fun, and the activities in the online were not interesting. Similarly, Ravi, R. C. (2020) stated that neither students nor educators feel excited because of the quality of activities during online classes.

In the study, "Classroom Engagement for University Students (CEUS)" was also applied to the students. The descriptive statistics of the responses given by 618 students from the year 1-6 are shown in Table 3.

Table 3

Classroom engagement levels of medical students

\begin{tabular}{lll}
\hline Items of Classroom Engagement for University Students & Mean (Std. Deviation) & Median (Min-Max) \\
\hline I feel happy in the class. & $3.12(1.03)$ & $3(1-5)$ \\
\hline I am highly interested in the classes. & $3.28(0.96)$ & $3(1-5)$ \\
\hline I see myself integrated with the classes. & $3.05(0.99)$ & $3(1-5)$ \\
\hline My sense of wonder is high in the class. & $3.35(0.96)$ & $3(1-5)$ \\
\hline Classes are fun for me. & $2.98(1.01)$ & $3(1-5)$ \\
\hline I orally participate in the classes. & $2.78(1.07)$ & $3(1-5)$ \\
\hline I answer the questions asked by the professor & $2.99(1.06)$ & $3(1-5)$ \\
\hline I participate in the activities in the classes. & $3.05(1.04)$ & $3(1-5)$ \\
\hline I am prepared for the classes. & $3.12(0.97)$ & $3(1-5)$ \\
\hline I ask questions to the professor when appropriate. & $3.10(1.07)$ & $3(1-5)$ \\
\hline I integrate what I have learned in the classes with other & $3.51(0.96)$ & $4(1-5)$ \\
information. & $3.54(0.96)$ & $4(1-5)$ \\
\hline I visualize what is being taught in the classes. & $3.51(0.95)$ & $4(1-5)$ \\
\hline I try to find examples for what is taught in the classes. & $3.50(0.94)$ & $3(1-5)$ \\
\hline I establish a connection with the real-life situations. & $3.56(0.95)$ & $4(1-5)$ \\
\hline I try to process the information taught during the classes. & & \\
\hline$N=618$ & &
\end{tabular}

$N=618$

In the items with high mean score in the CEUS scale, it was found that the students tried to integrate what they learned with other information in the lessons, they tried to visualize what was told, they tried to think about examples of what was told. On the other hand, the students stated that the classes were not fun, they did not orally participate in the classes, they were not willing to answer the questions. These findings are similar to the findings of the research conducted by Bock et al. (2020). It can be concluded from these findings that the students do not often participate in the class discussions.

In the study, "Curiosity and Exploration Inventory (CEI)" were applied to the students. The descriptive statistics of the responses given by 618 students from the year 1-6 are shown in Table 4 . 
Table 4

Medical students' curiosity and exploration levels

\begin{tabular}{lll}
\hline Items of Curiosity and Exploration Inventory & $\begin{array}{l}\text { Mean (Std. } \\
\text { Deviation) }\end{array}$ & $\begin{array}{l}\text { Median (Min- } \\
\text { Max) }\end{array}$ \\
\hline I actively seek as much information as I can in new situations. & $3.30(0.84)$ & $3(1-5)$ \\
\hline I am the type of person who really enjoys the uncertainty of everyday life. & $2.39(1.21)$ & $3(1-5)$ \\
\hline I am at my best when doing something that is complex or challenging. & $3.18(0.97)$ & $3(1-5)$ \\
\hline Everywhere I go, I am out looking for new things or experiences. & $3.39(0.99)$ & $3(1-5)$ \\
\hline I view challenging situations as an opportunity to grow and learn. & $3.33(0.98)$ & $3(1-5)$ \\
\hline I like to do things that are a little frightening. & $3.00(1.08)$ & $3(1-5)$ \\
\hline $\begin{array}{l}\text { I am always looking for experiences that challenge how I think about myself } \\
\text { and the world. }\end{array}$ & $3.11(1.05)$ & $3(1-5)$ \\
\hline I prefer jobs that are excitingly unpredictable. & $2.64(1.14)$ & $3(1-5)$ \\
\hline I frequently seek out opportunities to challenge myself and grow as a person. & $3.27(0.98)$ & $3(1-5)$ \\
\hline I am the kind of person who embraces unfamiliar people, events, and places. & $3.12(1.06)$ & $3(1-5)$ \\
\hline$N=618$ & &
\end{tabular}

In the responses given to the TCEI items, there were no items with a high mean score of students' curiosity and exploration. Means and medians were found to be at moderate level. The mean scores were low especially in the items related to uncertainty. To sum up, it can be said that medical students have moderate level of curiosity and exploration traits and they do not like uncertainty. These findings correlate with the findings of the research carried out by Randall and Villareal (2020) and Shepherd, Gauld, Cristancho and Chahine (2020) that medical students would like to have a more systematic way of learning rather than uncertainty, and although they are curious and would like to explore new things, if the activities and environment are not designed accordingly, they do not prefer to participate.

The impact of curiosity and exploration levels of medical students on classroom engagement and commitment to online learning environment was modelled by multivariate regression analysis. Results are indicated in Table 5.

Table 5

Prediction level of curiosity and exploration on the classroom engagement and student engagement in online learning environments

\begin{tabular}{|c|c|c|c|c|c|c|}
\hline \multirow{2}{*}{ Estimated } & \multirow{2}{*}{ Predictor } & \multirow{2}{*}{ Coefficient } & \multirow{2}{*}{$\mathrm{p}$} & \multicolumn{2}{|c|}{ 95\% Confidence Interval } & \multirow[t]{2}{*}{$R^{2}$} \\
\hline & & & & Lower & Upper & \\
\hline Behavioral & Flexibility & 0.30 & 0.0001 & 0.24 & 0.35 & \multirow{2}{*}{0.17} \\
\hline Commitment & Acceptance Uncertainty & -0.33 & 0.0001 & -0.40 & -0.26 & \\
\hline Affective & Flexibility & 0.01 & 0.876 & -0.10 & 0.12 & \multirow{2}{*}{0.06} \\
\hline Commitment & Acceptance Uncertainty & 0.33 & 0.0001 & 0.18 & 0.47 & \\
\hline Cognitive & Flexibility & 0.90 & 0.0001 & 0.79 & 1.01 & \multirow{2}{*}{0.30} \\
\hline Commitment & Acceptance Uncertainty & -0.64 & 0.0001 & -0.79 & -0.48 & \\
\hline Affective & Flexibility & 0.48 & 0.0001 & 0.40 & 0.57 & \multirow{2}{*}{0.26} \\
\hline Engagement & Acceptance Uncertainty & -0.06 & 0.325 & -0.17 & 0.06 & \\
\hline Behavioral & Flexibility & 0.34 & 0.0001 & 0.26 & 0.43 & \multirow{2}{*}{0.23} \\
\hline Engagement & Acceptance Uncertainty & 0.16 & 0.009 & 0.04 & 0.28 & \\
\hline Cognitive & Flexibility & 0.63 & 0.0001 & 0.55 & 0.70 & \multirow{2}{*}{0.36} \\
\hline Engagement & Acceptance Uncertainty & -0.23 & 0.0001 & -0.34 & -0.13 & \\
\hline
\end{tabular}

Flexibility and acceptance uncertainty, as the subfactors of curiosity and exploration, are significant predictors of "commitment" and "cognitive commitment" (subfactors of Student engagement in online learning environment $)(\mathrm{p}<.05)$. Whereas "flexibility" has a positive impact in these subfactors, "acceptance uncertainty" is a negative predictor. In other words, the increase in flexibility also 
increases the behavioral and cognitive commitment level. However, the increase in acceptance uncertainty decreased behavioral and cognitive commitment. Only acceptance uncertainty is the positive predictor for affective commitment. When acceptance uncertainty increases, affective commitment also increases.

Flexibility, as a subfactor of curiosity and exploration, is a significant positive predictor of affective, behavioral and cognitive engagement $(\mathrm{p}<.05)$. When flexibility increases, affective, behavioral and cognitive engagement also increase. Acceptance uncertainty, as a subfactor of curiosity and exploration, is a positive predictor for behavioral engagement but a negative predictor for cognitive engagement $(\mathrm{p}<.05)$. When acceptance uncertainty increases, behavioral engagement increases whereas cognitive engagement decreases. The R2 value gives the percentage of estimation on the estimated variable of the predictor variables in regression models. In the regression models, curiosity and exploration has the following levels of estimation:

- Classroom engagement on cognitive engagement (36\%)

- Student Engagement in Online learning environment on cognitive commitment (30\%)

- Classroom engagement on affective engagement (26\%)

- Classroom engagement on behavioral engagement (23\%)

- Student engagement in online learning environment on behavioral commitment $(17 \%)$

- Student engagement in online learning environment on affective commitment (6\%)

The curiosity and exploration levels of the students are higher than their perception of engagement in the face-to-face classes whereas it is lower in student engagement in online learning environment. Perception level of curiosity and exploration estimates cognitive level activities more than behavioral and affective level activities.

\section{CONCLUSION}

When flexibility, as a subfactor of curiosity and exploration, increases, behavioral and cognitive commitment (subfactors of student engagement in online learning environment) also increases. This result correlates with the research in the related literature that the students like different types and platforms that allows them to interact with the educators and peers at any time (Arantes do Amaral, \& Brito, 2018; Arantes do Amaral, \& Hess, 2017; Arbaugh, 2000; Nickerson \& Shea, 2020; McBrien, Cheng \& Jones, 2009; Simpson \& Anderson, 2012).

Another finding of the study is that the increase in the acceptance uncertainty (subfactor of curiosity and exploration) has a decreasing effect on behavioral commitment whereas it has an increasing effect in affective commitment. This finding is in line with the studies conducted by Kahn, Everington, Kelm, Reid and Watkins (2017), Tabak and Nguyen (2013). On the other hand, the increase in the acceptance uncertainty (subfactor of curiosity and exploration) also increases affective, behavioral, and cognitive engagement (subfactors of Student engagement in online learning environment). For example, the increase in acceptance uncertainty (subfactor of curiosity and exploration) has an increasing effect on behavioral engagement but a decreasing effect on cognitive engagement. These results are in line with the research conducted by Arbaugh and Benbunan-Finch (2006), Imlawi and Gregg (2014) and Lazareva (2017). Although the students' curiosity and exploration levels predict their engagement in face-to-face classes at a higher level, it predicts their engagement in online learning environments at a lower degree. The perception level of curiosity and exploration predicts cognitive activities better than the activities in behavioral and affective level. 
To improve students' engagement in online learning in general, the educators should use different platforms and tools to provide a more participatory learning environment, and these tools should aim to enhance learning through collaboration. In addition, different methods and techniques of teaching should be utilized to support the students learning.

\section{REFERENCES}

Acun, N., Kapıkıran, Ş., \& Kabasakal, Z. (2013). Merak ve keşfetme ölçeği II: Açımlayıcı ve doğrulayıcı faktör analizleri ve güvenirlik çalışması (Trait curiosity and exploration inventory-II: Exploratory and confirmatory factor analysis and its reliability). Türk Psikoloji Yazıları (Turkish Psychological Articles), 16(31), 74-85.

Aguilera Hermida, A. P. (2020). College students' use and acceptance of emergency online learning due to Covid-19. International Journal of Educational Research Open, 1, 100011. https://doi.org/10.1016/j.ijedro.2020.100011

Alabbasi, D. (2017). Exploring graduate students' perspectives towards using gamification techniques in online learning. Turkish Online Journal of Distance Education, 18(3), 180-196. https://doi.org/10.17718/tojde.328951

Arantes do Amaral, J. A., \& Brito, S. C. (2018). Using the arts to foster students' interest, engagement, and learning in a distance-learning environment. Anatolian Journal of Education, 3(2), 1-18. https://doi.org/10.29333/aje.2018.321a

Arantes do Amaral, J. A., \& Hess, A. (2017). What drives the viewership of an online video-lecture course? A case study. Anatolian Journal of Education, 2(1), 21-33.

Arbaugh, J. B. (2000). How classroom environment and student engagement affect learning in Internet-based MBA courses. Business Communication Quarterly, 63(4), 9-26. https://doi.org/10.1177/108056990006300402

Arbaugh, J. B., \& Benbunan-Finch, R. (2006). An investigation of epistemological and social dimensions of teaching in online learning environments. Academy of Management Learning \& Education, 5(4), 435-447. https://doi.org/10.5465/amle.2006.23473204

Bozkurt, A., \& Sharma, R. C. (2020). Emergency remote teaching in a time of global crisis due to Corona Virus pandemic. Asian Journal of Distance Education, 15(1), i-vi. https://doi.org/10.5281/zenodo.3778083

Bozkurt, A., Jung, I., Xiao, J., Vladimirschi, V., Schuwer, R., Egorov, G., ... \& Rodes, V. (2020). A global outlook to the interruption of education due to COVID-19 Pandemic: Navigating in a time of uncertainty and crisis. Asian Journal of Distance Education, 15(1), 1-126.

Brouns, F., Teixeira, A., Morgado, L., Fano, S., Fueyo, A., \& Jansen, D. (2017). Designing massive open online learning processes: The sMOOC pedagogical framework. In Open Education: from OERs to MOOCs (pp. 315-336). Springer, Berlin, Heidelberg.

Christensen, L. B., Johnson, R. B. \& Turner, L. A. (2014). Research methods, design, and analysis. The USA: Pearson Education.

Dumford, A. D., \& Miller, A. L. (2018). Online learning in higher education: exploring advantages and disadvantages for engagement. Journal of Computing in Higher Education, 30(3), 452-465. https://doi.org/10.1007/s12528-018-9179-z

Ergün, E., \& Koçak Usluel, Y. (2015). Çevrimiçi öğrenme ortamlarında öğrenci bağlllık ölçeğinin Türkçe uyarlaması: Geçerlik ve güvenirlik çalışması (The Turkish adaptation of student's engagements 
scale in online learning environment: A study of validity and reliability). Eğitim Teknolojisi Kuram ve Uygulama (Educational Technology Theory and Practice), 5(1), 20-33. https://doi.org/10.17943/etku.64661

Eryılmaz, A. (2014). Üniversite öğrencileri için derse katılım ölçeklerinin geliştirilmesi (The development of the scales of classroom engagement for university students). Uşak Üniversitesi Sosyal Bilimler Dergisi (Usak University Journal of Social Science), 7(2), 203-214. https://doi.org/10.12780/UUSBD356

Everitt, B. S., \& Howell, D. C. (2005). Encyclopedia of statistics in behavioral science. The UK: John Willey and Sons

Farrell, O., \& Brunton, J. (2020). A balancing act: a window into online student engagement experiences. International Journal of Educational Technology in Higher Education, 17, 1-19. https://doi.org/10.1186/s41239-020-00199-x

Field, A. (2018). Discovering statistics using IBM SPSS Statistics. The USA: Sage.

Ferreira, D., MacLean, G., \& Center, G. E. (2018). Andragogy in the 21st century: Applying the assumptions of adult learning online. Language Research Bulletin, 32(11), 10-19.

Fraenkel, J. R., Wallen, N. E., \& Hyun, H. H. (2012). How to design and evaluate research in education. The USA: McGraw Hill.

Hediansah, D., \& Surjono, H. D. (2019). Building motivation and improving learning outcomes with android-based physics books: Education 4.0. Anatolian Journal of Education, 4(2), 1-10. https://doi.org/10.29333/aje.2019.421a

Hodges, C., Moore, S., Lockee, B., Trust, T., \& Bond, A. (2020). The difference between emergency remote teaching and online learning. Educause Review. https://er.educause.edu/articles/2020/3/thedifference-between-emergency-remote-teaching-and-onlinelearning.

Imlawi, J., \& Gregg, D. (2014). Engagement in online social networks: The impact of self-disclosure and humor. International Journal of Human-Computer Interaction, 30(2), 106-125. https://doi.org/10.1080/10447318.2013.839901

Kahn, P., Everington, L., Kelm, K., Reid, I., \& Watkins, F. (2017). Understanding student engagement in online learning environments: The role of reflexivity. Educational Technology Research and Development, 65(1), 203-218. https://doi.org/10.1007/s11423-016-9484-z

Kashdan, T. B., Gallagher, M. W., Silvia, P. J., Winterstein, B. P., Breen, W. E., Terhar, D.T. ve Steger, M. F. (2009). The curiosity and exploration inventory-II: Development, factor structure, and psychometrics. Journal of Research in Personality, 43, 987-998. https://doi.org/10.1016/j.jrp.2009.04.011

Kim, T. D., Yang, M. Y., Bae, J., Min, B. A., Lee, I., \& Kim, J. (2017). Escape from infinite freedom: Effects of constraining user freedom on the prevention of dropout in an online learning context. Computers in Human Behavior, 66, 217-231. https://doi.org/10.1016/j.chb.2016.09.019

Lazareva, A. (2017, September). Factors Affecting Student Engagement in Online Collaborative Learning Courses. In International Conference on Interactive Collaborative Learning (pp. 349-359). Springer, Cham. 
McBrien, J. L., Cheng, R., \& Jones, P. (2009). Virtual spaces: Employing a synchronous online classroom to facilitate student engagement in online learning. International Review of Research in Open and Distributed Learning, 10(3), 1-17. https://doi.org/10.19173/irrodl.v10i3.605

McMillan, J., \& Schumacher, S. (2014). Research in education evidence-based inquiry. The UK: Pearson Education.

Nickerson, L. A., \& Shea, K. M. (2020). First-semester organic chemistry during COVID-19: prioritizing group work, flexibility, and student engagement. Journal of Chemical Education, 97(9), 3201-3205. https://doi.org/10.1021/acs.jchemed.0c00674

Pallant, J. (2016). SPSS survival manual. The USA: McGraw-Hill Education.

Polat, M. (2020). Measuring language learners' success oriented motivation. Anatolian Journal of Education, 5(2), 151-162. https://doi.org/10.29333/aje.2020.5213a

Rajab, M. H., Gazal, A. M., \& Alkattan, K. (2020). Challenges to online medical education during the COVID-19 pandemic. Cureus, 12(7). https://doi.org/10.7759/cureus.8966

Randall, V., \& Villareal, C. (2020). 'It's Okay to Say'I Don't Know": Medical Students Use Transformative Thinking to Cope with Ambiguity and Uncertainty. MedEdPublish, 9.

Ravi, R. C. (2020). Lockdown of colleges and universities due to COVID-19: Any impact on the educational system in India?. Journal of Education and Health Promotion, 9.

Roddy, C., Amiet, D. L., Chung, J., Holt, C., Shaw, L., McKenzie, S., ... \& Mundy, M. E. (2017, November). Applying best practice online learning, teaching, and support to intensive online environments: An integrative review. In Frontiers in Education (Vol. 2, p. 59). Frontiers.

Shepherd, L., Gauld, R., Cristancho, S. M., \& Chahine, S. (2020). Journey into uncertainty: Medical students' experiences and perceptions of failure. Medical Education, 54(9), 843-850.

Simpson, M., \& Anderson, B. (2012). History and heritage in open, flexible and distance education. Journal of Open, Flexible, and Distance Learning, 16(2), 1-10.

Sun, J. C.-Y., \& Rueda, R. (2012). Situational interest, computer self-efficacy and self regulation: Their impact on student engagement in distance education. British Journal of Educational Technology, 43(2), 191-204. https://doi.org/10.1111/j.1467-8535.2010.01157.x

Tabachnick, B. G., \& Fidell, L. S. (2013). Using multivariate statistics. The USA: Pearson Education.

Tabak, F., \& Nguyen, N. T. (2013). Technology acceptance and performance in online learning environments: Impact of self-regulation. Technology, 9(1), 116-130.

Yildırım, K. (2020). Lessons from an exceptional distance education experience. Alanyazın, 1(1), 715. https://doi.org/10.22596/cresjournal.0101.7.16

Zheng, B., \& Zhang, Y. (2020). Self-regulated learning: the effect on medical student learning outcomes in a flipped classroom environment. BMC Medical Education, 20, 1-7. 